JINOTEP 5 (1) Oktober (2018): 8-14 JINOTEP (Jurnal Inovasi Teknologi Pembelajaran) Kajian dan Riset Dalam Teknologi Pembelajaran http://journal2.um.ac.id/index.php/jinotep/index

\title{
PEMBELAJARAN MODEL PROJECT-BASED TEACHING PRACTICES BERBANTUAN WEB PADA MATERI PERENCANAAN DAN PEMUTAKHIRAN JARINGAN
}

\author{
Mochamad Farid Yusuf, Sihkabuden, Henry Praherdhiono \\ Teknologi Pembelajaran, Universitas Negeri Malang
}

\section{Article History \\ Received: Sept 23, 2018 \\ Accepted: March 22, 2019}

Published:March 23, 2019

\section{Keywords}

Pembelajaran di SMK

Project-based Teaching

Practices

Berbantuan Web

Perencanaan dan

Pemutakhiran Jaringan

\begin{abstract}
Abstrak
Tujuan pembelajaran di SMK (Sekolah Menengah Kejuruhan) adalah mencetak siswa mempunyai keterampilan dan pengetahuan yang mumpuni. Keterampilan dan pengetahuan didapat secara nyata dari hasil pembelajaran dengan model proyek. Penelitian ini bertujuan merancang desain pembelajaran yang mampu memenuhi kebutuhan siswa secara personal untuk meningkatkan ketrampilan bekerja dan keahlian dibidang perencanaan dan pemutakhiran jaringan serta kebutuhan akan waktu dan tempat selama belajar di sekolah. Desain pembelajaran model project-based teaching practices berbantuan web bisa menjadi solusi permasalahan yang ada. Pengembangan menggunakan model Lee dan Owen (2004). Produk pengembangan ini menghasilkan desain pembelajaran yang dikemas dalam teknologi web.
\end{abstract}

\section{Abstract}

The purpose of learning in SMK (Junior High School) is to pproduce students who have the skills and knowledge that qualified. Skills and knowledge are gained significantly from the learning outcomes with the project model. This study aims to improve the ability of individuals to improve the skills of work and skills required and network updates and the need for time and place during school studies. Web-enhanced instructional model of project-based teaching can be an existing solution. The development design is a development model of Lee and Owen (2004). This development product produces a learning design packaged in web technology.
Corresponding author :

Mochamad Farid Yusuf,

Teknologi Pembelajaran

Pascasarjana Universitas Negeri Malang

Jalan Semarang No.5 Malang

E-mail: faridyusuf6@gmail.com
2018 Universitas Negeri Malang p-ISSN 2406-8780 e-ISSN 2654-7953 


\section{PENDAHULUAN}

Pengertian pembelajaran memiliki makna yang luas karena beberapa tokoh memiliki konstruksi pemikiran yang berbedabeda. Pembelajaran menurut Smith \& Ragan (1999) adalah proses sistematis dan reflektif untuk menerapkan prinsip pembelajaran dalam rencana pembelajaran itu sendiri. Pada proses pembelajaran yang digunakan berfase logis dan sitsematis dalam mencapai tujuan. Pada era digital sekarang ini kemajuan teknologi informasi dan komunikasi mengalamai perkemabangan yang sangat tidak terbendung, kemajuan pada bidang komputer dan jaringan internet menjadi peluang besar untuk dimanfaatkan dan digunakan dalam menunjang kebutuhan belajar pada pebelajar di era digital ini.

Pembelajaran di SMK (Sekolah Menengah Kejuruhan) bertujuan untuk melatih dan membekali para siswanya menjadi ahli dan terampil dibidang ilmu terapan. Sehingga keahlian secara individu menjadi hal yang paling utama untuk dicapai oleh setiap siswa yang bersekolah di SMK. Menurut Peraturan Pemerintah No 17 (Indonesia, 2010) Mengatakan bahwa pada dasarnya kurikulum sekolah SMK adalah pendidikan menengah yang menerapkan pendidikan vocational yang menerapkan pembelajaran yang berbasis ketrampilan dan proyek. Dalam hal ini sekolah menengah kejuruan membutuhkan rancangan pembelajaran yang mampu memenuhi kebutuhan belajarnya berupa ketrampilan dan keahlian merancang proyek melalui teknologi informasi dan komunikasi. Pada salah satu materi yang ada pada Jurusan Teknik Komputer dan Jaringan di SMK adalah materi mengenai perencaan dan pemutakhiran jaringan. Perencanaan dan pemutakiran jaringan adalah materi yang mempelajari bagaimana merancang dan memutakirkan jaringan pada wilayah tertentu seperti institusi, lembaga, dan masyarakat luas.Tujuan dari materi tersebut adalah membekali siswa untuk terampil dalam merancang suatu jaringan sesuai dengan kebutuhan lembaga, institusi. Perancang merupakan ahli desain jaringan dengan kompetensi meningkatkan kualitas jaringan yang dibangun sesuai dengan kebutuhannya.

Pembelajaran yang berorientasi tujuan, perlu mendapat dukungan desain pembalajaran. Pembelajaran secara proses dibutuhan suatu rancangan pembelajaran yang mampu mengakomodasi siswa dalam menerapkan materi tersebut. Materi dalam pembelajaran berbantuan web secara umum merupakan learning object yang terbuka (Praherdhiono \& Pramono Adi, 2017). Perencaan dan Pemutakhiran jaringan adalah materi yang cocok dipelajari dengan cara menggunakan model pengajaran praktis berbasis proyek (Project-based teaching Practices) (Larmer, Mergendoller, \& Suzie, 2015).

Penilaian kebutuhan memerlukan observasi dan survey di SMKN 5 Malang. Pada kegiatan tersebut menemukan bahwa model pembelajaran yang diterapkan disekolah tersebut masih menggunakan model klasikal dengan metode ceramah. Pebelajar memiliki gaya belajar yang berbeda antara lain 1) gaya belajar auditori, 2) visual auditori dan 3) kinestetik. Tetapi peneliti menemukan gaya pebelajar yang ada pada mayoritas kelas XI TKJ-2 adalah gaya belajar visual auditori. Pada temuan selanjutnya peneliti menemukan bahwa kebiasaan kurangnya minat baca pada siswa pada kelas tersebut disebabkan karena sumber belajar yang ada adalah buku teks dan buku sekolah elektronik, sehingga dari segi sumber belajar kurang bisa memenuhi gaya belajar siswa yang bereneka ragam. Sebagian besar siswa didapati cenderung menyukai belajar dengan perangkat elektronik seperti laptop dan smarthphone, peneliti juka menemukan kurangnya waktu disekolah untuk belajar.

Hasil survey mengenai sarana dan prasarana di sekolah tersebut peneliti memperoleh data berupa sarana teknologi seperti akses internet 1) cukup stabil menjadi sarana utama untuk bisa dimanfaantakan oleh siswa dalam memenuhi kebutuhan belajarnya, 2) siswa juga diwajibkan mempunyai perangkat elektronik berupa laptop untuk siswa pada jurusan Teknik Komputer dan Jaringan. 
10 JINOTEP (Jurnal Inovasi dan Teknologi Pembelajaran) Kajian dan Riset dalam Teknologi Pembelajaran Vol. 5, No. 1, Oktober 2018, Hal. 8-14

Berdasarkan hasil survey dan observasi tersebut peniliti mempunyai solusi dari permasalahan tersebut yaitu berupa rancangan pembelajaran Model Project-Based Teaching Practices berbantuan Teknologi web. Peneliti berasumsi bahwa pembelajaran berbantuan web memiliki kekayaan sumber belajar dengan memanfaatkan teknologi multimedia (Animasi,gambar, audio, video, Teks,) dan hypermedia (hyperlink) yang mampu mengakomodasi gaya belajar siswa yang beraneka ragam dan menjangkau siswa dalam keterbatasan waktu dan tempat untuk belajar, teknologi web dikenal sangat fleksibel dan ringan serta mampu beroprasi banyak platform computer. Sama halnya pendapat yang dikemukakan oleh (Bin, 2014) "Sumber belajar mengandung materi elektronik, hyperlink dan situs web yang relevan dari basis data asli. Jika siswa memiliki pertanyaan guru dapat menjawab secara online pertanyaan yang diajukan segera setelah siswa mengajukan pertanyaan."

\section{METODE}

Pengebangan pembelajaran mrtupakan model (Lee \& Owens, 2004). Peneliti memilih desain penelitian dan pengembangan tersebut dalam beberapa pertimbangan. Pertibangan pemilihan adalah model penelitian dan pengembangan tersebut berfokus pada penelitian dan pengembangan pembelajaran berbasis multimedia, model penelitian dan pengembangan ini juga befokus pada desain pembelajaran berbasis web dan pembelajaran online. Berdasarkan pertimbangan tersebut peneliti berasumsi bahwa model penelitian dan pengembangan (Lee \& Owens, 2004) cocok dengan desain pembelajaran model projectbased teaching practices berbantuan web.

Langkah-langkah atau prosedur dalam penelitian pengembangan tersebut adalah sebagai berikut:

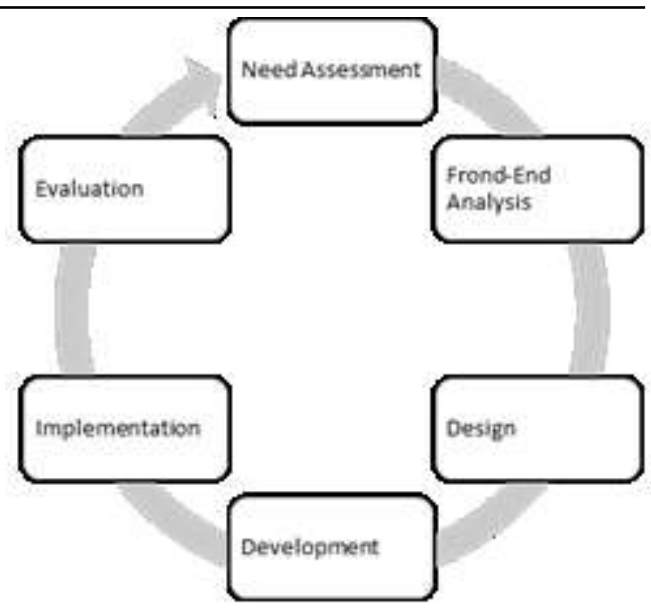

Gambar 1 Model Pengembangan Lee \& Owens

Berikut penjelasan langkah-langkah model penelitian dan pengembangan Lee \& Owens

1) Need Assessment: merupakan proses sistematis dalam menentukan tujuan akhir hasil pengembangan pembelajaran, megidentifikasi perbedaan kondisi sebenarnya dengan kondisi diharapkan untuk menentukan prioritas tindakan. Hasil dari penilaian kebutuhan adalah pembelajaran pada mater perencanaan dan pemutakiran jaringan masih menggunakan metode klasikal dengan ceramah sehingga mengakibatkan siswa kurang termotivasi secara intrinsic, belum tersedianya desain pembelajaran yang mampu memberikan pengelaman nyata dan motivasi secara intrinsic pada siswanya.

2) Front-end Analysis: tahap ini merupakan tahap analisis secara keseluruhan, tujuan dari analisis ini adalah mendapatkan data sebanyak yang dibutuhkan mulai data peserta didik, data ketersediaan teknologi, data kondisi dilapangan, data masalah yang ada, data analisis dari tugas, analisis dari tujuan pembelajaran, dan analisis media yang digunakan. Hasil dari analisis keseluruhan adalah siswa atau peserta didik cenderung menyukai belajar secara mandiri, pada pembelajaran perencaan dan pemutakiran jaringan seharusnya menggunakan model proyek, berdasarkan karakteristik dari materi perencanaan dan pemutakiran jaringan

3) Design: pada tahap design (perancangan) peneliti merancang penjadwalan dalam pengerjaaan rancangan pembelajaran, memilih tim proyek, menentukan spesifikasi media, merancang strutktur isi pembelajaran, dan merancang control kualitas. Penjadwalan untuk 
proses perancangan sampai proses evaluasi dan ujicoba dilaksanakan selama 3 bulan.

4) Development: pada tahap pengembangan perancang mengembangkan produk mulai dari menentukan jenis produk yang akan dikembangkan, mengumpulkan komponen, menentukan ulasan, melatih presentasi dan menentukan sesi. Produk pengembangan dikemas dalam LMS Schoology, sehingga sebagian proses pembelajaran dilaksanakan dengan cara online.

5) Implementation: pada tahap ini peneliti dan anggota tim melaksanakan serangkaian ujicoba yang telah dijadwalkan untuk memperoleh data hasil ujicoba produk yang telah dikembangkan. Pada pelaksanaan produk pembelajaran yang telah dikembangkan juga dilengkapi dengan buku petunjuk pelaksanaan sebagai pegangan untuk guru dalam merancang pembelajaran berbantuan web. Berikut ini disajikan buku petunjuk pelaksanaan pembelajaran:

Cover depan

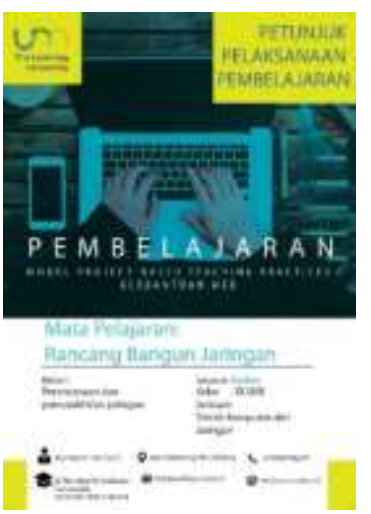

6) Evaluation: tahap ini adalah tahap terakir dari model penelitian dan pengembangan yang dilakukan berdasarkan model penelitian dan pengembangan (Lee \& Owens, 2004), pada tahap ini peneliti hanya menguji hanya sampai pada tahap evaluasi formatif dikarenakan produk yang diuji hanya sebatas sub bab materi pada mata pelajaran Rancang Bangun Jaringan.

Tingkat kelayakan, validitas, dan keefektifan suatu produk pembelajaran dilakukan serangkaian ujicoba produk yang mengacu pada desain ujicoba produk. Langkah yang diambil dalam ujicoba produk adalah sebagai berikut: (1) Dilakukan review oleh ahli (ahli Desain
Pembelajaran, Ahli Media Pembelajaran, Ahli Materi Pembelajaran) dan ujicoba pada audien (Kelompok Besar, Kelompok Kecil, dan Perorangan).

Proses analisis data terdapat aturan dan prosedur yang harus diikuti, untuk mengukur tingkat kevalidan suatu produk berdasarkan acuan yang telah ditetapkan berikut acuan tersebut:

1. Menghitung persentase keseluruhan pada instrumen menurut (Arikunto, 2002)

$\mathbf{P}=\frac{F}{A} 100 \%$

Dengan:

$\mathrm{P}=$ Persentase

$\mathrm{F}=$ Jumlah skor yang diperoleh

$\mathrm{A}=$ Jumlah skor maksimum

Tabel 1. Kriteria tingkat validitas yang

berkaitan dengan hasil analisis data

\begin{tabular}{|c|c|c|}
\hline Persentase & Kriteria & Ekuivalen \\
\hline $80 \%-100 \%$ & valid & Layak \\
\hline $60 \%-79 \%$ & Cukup valid & Cukup layak \\
\hline $30 \%-59 \%$ & Kurang valid & Kurang Layak \\
\hline $0 \%-29 \%$ & Tidak valid & Tidak Layak \\
\hline
\end{tabular}

2. Mengukur tingkat keefektifan:

$\mathbf{P}=\frac{\Sigma \mathrm{x}}{\Sigma \mathrm{x} 1} 100 \%$

Dengan:

- $\mathrm{P}=$ Persentase

- $\Sigma \mathrm{x}=$ Jumlah keseluruhan siswa yang telah mencapai standar skor penilaian

$\Sigma \mathrm{x} 1=$ Jumlah keseluruhan siswa 
12 JINOTEP (Jurnal Inovasi dan Teknologi Pembelajaran) Kajian dan Riset dalam Teknologi Pembelajaran Vol. 5, No. 1, Oktober 2018, Hal. 8-14

\section{HASIL}

Hasil dari penelitian dan pengembangan ini berupa desain pembelajaran yang mengacu pada model project-based teaching practices dan disajikan memanfaatkan teknologi web sebagai media penyampaian informasi. Secara keselurhan interaksi yang ada sebagian besar berada pada lingkungan belajar online. Produk pembelajaran ini berisi tentang materi perencanaan dan pemutakiran jaringan diperuntukan pada siswa kelas XI Jurusan TKJ di SMKN 5 Malang. Produk pembelajaran ini memanfaatkan LMS (Learning Management System) Schoology sebagai platform kerangka utama produk pembelajaran.

Produk pembelajaran ini dirancang dan dikembangkan berdasarkan hasil dari penilaian kebutuhan dan analisis secara mendalam yang dilaksanakan di kelas XITKJ-2 di SMKN 5 Malang, maka produk pembelajaran model project-based Teaching Practices Berbantuan web ini sangat dibutuhkan untuk digunakan dalam pembelajaran pada materi perencaan dan pemutakiran jaringan.

\section{Deskripsi Produk}

Penelitian dan pengembangan menghasilkan produk berupa desain pembelajara berlandaskan model project-based Teaching Practices berbantuan web. Desain pembelajaran yang dihasilkan ditujukan pada materi perencanaan dan pemutakiran jaringan pada siswa SMK Jurusan Teknik Komputer dan jaringan. Pada produk pengembangan pembelajaran berikut ini dilengkapi dengan buku petunjuk pelaksanaan pembelajaran yang berisi mengenai deskripsi program, latar belakang singkat mengenai alasan tentang pengembangan desain pembelajaran, alasan pemilihan LMS Schoology sebagai platform, Rencana Pelaksanaan Pembelajaran (RPP), dan petunjuk pengoprasian LMS Schoology. Pada penyajian materi yang ada pada LMS yschoology dasajikan dengan memanfaatkan semua fitur yang ada pada LMS schoology. Kemudahan yang ditawarkan produk pembelajaran berbantuan web ini adalah fitur hypermedia dan multimedia dimana semua komponen multimedia disajikan secara berurutan desesuaikan dengan bobot pemahaman materi konsep yang akan disajikan. Sedangkan pada evaluasi terdapat pengukuran bobot penilaian secara otomatis mengacu pada rubrik penilaian yang telah dirancang sebelumnya.

Ujicoba produk desain pembelajaran dilakukan dalam 6 tahapan. Tahap tersebut harus dilalui siswa untuk mencapai tujuan pembelajaran tentang materi perencanaan dan pemutakhiran jaringan, keenam langkah tersebut adalah sebagai berikut: Pendahuluan,berisi tentang pengenalan alasan mengenai mengapa diadakan proyek pembelajaran perencanaan dan pemuthikran jaringan, interaksi yang dilakukan berupa tatapmuka, (2) Materi perencanaan dan pemutakhiran jaringan \& prasyarat,tipe interaksi online, (3) materi dokumentasi jaringan dan simulasi, tipe interaksi adalah online, (4) Survey lapangan, tipe interaksi adalah tatap muka dan bekerja secara tim, (5) presentasi hasil survey $\&$ simulasi tipe interaksi adalah online, (6) evaluasi, tipe interaksi adalah online.

\section{Penyajian Data Hasil Ujicoba Produk Dan Uji Efektifitas Produk}

Dalam mengukur tingkat validitas, kelayakan, dan efektifitas produk pembelajaran yang telah diujicobakan terdapat serangkaian tahapan yang harus dilalui mulai dari uji para ahli, ahli desain pembelajaran, ahli materi pembelajaran dan ahli media pembelajaran dan ujicoba oleh para audien. Untuk mengukur tingkat validitas terdapat alat berupa angket ahli yang berisi intrumen yang mewakili prinsip atau aturan berdasarkan tingkat validitas produk pembelajaran, kemudian hasil uji dengan alat berupa angket tersebut dianalisis dan dibuat persentasi yang hasilnya disajikan sebagai berikut: 


\begin{tabular}{|c|c|c|c|c|}
\hline \multicolumn{5}{|c|}{$\begin{array}{c}\text { Tabel } 2 \text { Data Hasil Uji Coba dan Test Hasil } \\
\text { Belajar }\end{array}$} \\
\hline No & Langkah & $\begin{array}{c}\text { Hasil yang } \\
\text { diperoleh }\end{array}$ & $\begin{array}{l}\text { Rentang } \\
\text { ukuran } \\
(\%)\end{array}$ & Kriterian \\
\hline 1 & $\begin{array}{l}\text { Uji Ahli Desain } \\
\text { Pembelajaran }\end{array}$ & $94 \%$ & $\begin{array}{l}76 \%- \\
100 \%\end{array}$ & Valid \\
\hline 2 & $\begin{array}{l}\text { Uji Ahli Media } \\
\text { Pebelajaran }\end{array}$ & $92 \%$ & $\begin{array}{l}76 \%- \\
100 \%\end{array}$ & Valid \\
\hline 3 & $\begin{array}{l}\text { Uji Ahli Materi } \\
\text { Pembelajaran }\end{array}$ & $92 \%$ & $\begin{array}{l}76 \%- \\
100 \%\end{array}$ & Valid \\
\hline 4 & $\begin{array}{l}\text { Uji Coba } \\
\text { Perorangan }\end{array}$ & $88 \%$ & $\begin{array}{l}76 \%- \\
100 \%\end{array}$ & Valid \\
\hline 5 & $\begin{array}{l}\text { Uji Coba } \\
\text { Kelompok Kecil }\end{array}$ & $87 \%$ & $\begin{array}{l}76 \%- \\
100 \%\end{array}$ & Valid \\
\hline 6 & $\begin{array}{l}\text { Uji Coba } \\
\text { Kelompok } \\
\text { Besar }\end{array}$ & $91 \%$ & $\begin{array}{l}76 \%- \\
100 \%\end{array}$ & Valid \\
\hline 7 & $\begin{array}{l}\text { Test Hasil } \\
\text { Belajar }\end{array}$ & $88,3 \%$ & $\begin{array}{l}80 \%- \\
100 \%\end{array}$ & Efektif \\
\hline
\end{tabular}

\section{PEMBAHASAN}

Berdasarkan data yang dieperoleh dari uji coba ahli dan audien pada pelaksanaan produk hasil pengembangan yang diadakan di SMKN 5 Malang diperoleh data yang valid berdasarkan sekala yang tela ditetapkan berdasarkan (Arikunto, 2002). Hasil uji validitas dan efektifitas didapat dari penilaian dari ahli dan audien. Hasil penilaian dan tanggapan berupa kritik dan saran oleh para ahli dan audien menjadi bahan pertimbangan untuk revisi produk yang telah dikembangkan. Revisi produk bertujuan untuk mengurangi tingkat kesalahan, dan kekurangan yang ada pada produk pembelajaran model project-based teaching practices berbantuan web.

\section{Revisi Produk}

Revisi produk bertujuan untuk mengurangi tingkat kesalahan dan kekurangan dari review produk yang telah dikembangkan. Revisi produk dilakukan berdasarkan tanggapan berupa saran dari ahli media dan analisis penilaian setiap butir instrumen pertanyaan yang dinilai tidak diberi nilai penuh oleh para ahli dan audiens.

Masukan dari ahli desain pembelajaran, kesalahan ditemukan oleh ahli desain pembelajaran terdapat pada indikator pencapaian kompetensi pada Rencana
Pelaksanaan Pembelajaran dan Kriteria Penilaian yang ada pada rubrik penilaian di RPP. Saran perbaikan dari ahli desain pembelajaran yaiu mengganti indikator pencapaian kompetensi yang semula"siswa mampu mengerti. .." dan menjabarkan secara kongkret menjadi "siswa mampu mengaplikasikan. ..."

Masukan dari ahli media pembelajaran, hasil penilaian dari ahli media pembelajaran sebagian besar tidak ada kesalahan yang fatal sehingga ahli media menyearankan untuk tidak perlu ada revisi dari segi media pembelajaran.

Masukan dari ahli materi pembelajaran, pada penyajian materi yang ada pada course " Rancang Bangun Jaringan: Perencanaan dan Pemutakhiran Jaringan" ahli materi menyarankan untuk menambahkan mindmap dalam tujuan pembelajaran.

Masukan dari audien, sebagian besar tidak ada masukan untuk perbaikan dalam produk pembelajaran ini sehingga peneliti menganggap tidak perlu adanya revisi produk berdasarkan tanggapan dari audien.

\section{SIMPULAN DAN SARAN Simpulan}

Hasil produk pengembangan ini menghasilkan isi materi mengenai perencanaan dan pemutakiran jaringan yang pada intinya adalah mempelajari bagaimana seorang perancang jaringan mampu secara pengentahuan dan keterampilan membangun jaringan sesuai dengan kebutuhan dan keperluannya. Produk dari hasil pengembangan ini juga telah melalui beberapa proses validasi yang dilakukan oleh peneliti yang menghasilkan, penilaian dari ahli desain pembelajaran sebesar $94 \%$ yang secara acuan sudah dikatakan valid, ahli media pembelajaran memberikan penilaian $92 \%$ yang secara acuan sudah dapat dikatakan valid, ahli materi pembelajaran memberikan penilaian sebesar 92 $\%$ yang secara acuan sudah dapat dikatakan valid, dan penilaian audien sebesar $87 \%$ yang secara acuan sudah dapat dikatakan valid. Sedangkan untuk tes hasil belajar rata-rata 
14 JINOTEP (Jurnal Inovasi dan Teknologi Pembelajaran) Kajian dan Riset dalam Teknologi Pembelajaran Vol. 5, No. 1, Oktober 2018, Hal. 8-14

keberhasilan siswa mencapai $88,3 \%$ yang secara acuan sudah dapat dikatakan efektif. Berdasarkan hasil paparan penilaian yang dilakukan produk pembelajaran model projectbased teaching practices berbantuan web dikategorikan valid dan efektif digunakan dalam pembelajaran pada materi perencanaan dan pemutakiran jaringan.

\section{Saran}

Saran pemanfaatan ditujukan untuk memaksimalkan produk yang telah dikembangkan. Bagi pihak yang akan memanfaatkan produk pengembangan desain pembelajaran model project-based teaching practices berbabtuan web ini agar mempertimbangkan dari segi kurikulum, sarana dan prasarana, karakteristik materi agar disesuaikan dengan kondisi siswa dan kebutuhan siswa. Pada kurikulum sebaiknya menyesuaikan dengan model pembelajaran berbasi proyek yang memang diperuntukkan pada mata pelajaran yang mempunyai karakteristik menghasilkan produk dan keahlian secara personal siswanya. Dari segi saran dan prasarana sebaiknya memperhatikan teknologi yang tersedia dan aksest internet yang stabil untuk membantu kelancaran pembelajaran pada materi perencanaan dan pemutakhiran jaringan.

\section{DAFTAR RUJUKAN}

Arikunto, S. (2002). Prosedur penelitian: suatu pendekatan praktek / Suharsimi Arikunto. Jakarta: Rineka Cipta.

Bin, J. (2014). Web-based Cooperative Learning in College Chemistry Teaching. IJet, 1-3

Indonesia, P. R. Pereaturan Pemerintah Republik Indonesia Tentang Penyelenggaraan Pendidikan, Pub. L. No. 17, 1 (2010). Indonesia

Larmer, J., Mergendoller, J., \& Suzie, B. (2015). Setting the Standard for Project Based Learning. Virginia: ASCD

Lee, W. W., \& Owens, D. L. (2004). MultimediaBased Instructional Desig

Praherdhiono, H., \& Pramono Adi, E. (2017). Constructing Learning Results as Learning Object Through Open Learning System. Atlantis Press. https://doi.org/10.2991/icet17.2017.5

Smith, P. L., \& Ragan, T. J. (1999). Instructional Design Second Edition. New York: John Wiley \& Sons, Inc. 